to be able to plot national or regional variations in incidence. Furthermore, such notifications will enable the treatment and education of the surviving children to be planned at an early stage. A pamphlet ${ }^{3}$ accompanying the letter which introduces the scheme points out that at 4.4 per 1,000 in 1961 the infant death rate from malformations differed little from that in 1901-5, and that $21 \%$ of present-day infant deaths are due to this cause. About $15 \%$ of all malformed children are stillborn, while $30 \%$ die within the first year of life. As to the aetiology of congenital malformations, recent events have focused particular attention on drugs in early pregnancy, but other known or suspected causes include virus infections, nuclear radiation, imbalance of diet or hormones, and abnormal conditions in utero, such as malpresentation or external pressure. The booklet also emphasizes that some congenital malformations, such as heart disease, may not be immediately apparent ; others, such as congenital dislocation of the hip, may need to be specifically excluded by physical examination. It is likely, therefore, that some abnormalities, particularly minor ones, may escape detection in the neonatal period and fail to be notified altogether. Possibly some machinery for notifying subsequently detected malformations may be found to be necessary, as has been suggested before. ${ }^{4}$ It is known that large-scale studies may seriously underestimate the incidence of malformations, while official notification schemes in some parts of the United States have been found to be seriously incomplete. ${ }^{5}$ Clearly much will depend on the vigilance and co-operation of the general practitioner and the hospital doctor, but the patience and enthusiasm shown in earlier surveys ${ }^{6}{ }^{7}$ suggest that these will not be lacking in the new scheme.

\section{New Year Honours}

The advancement of Sir Charles Dodds, P.R.C.P., F.R.S., to a baronetcy is further recognition of his remarkable contributions to medical science. Appointed professor of biochemistry at the Middlesex Hospital Medical School when only 26 years old, he soon came to the fore as one of the biochemists who have revolutionized the practice of medicine in the last few decades. His election to the Fellowship of the Royal Society in 1942 honoured his achievements in unravelling the sex hormones and notably in synthesizing stilboestrol and related compounds. For just on 40 years "Beaumont and Dodds" - to give the familiar title of Recent Advances in Medicinehas been a mine of information for everyone and especially those sitting for the M.R.C.P. examination. Dodds's impact on clinical medicine has indeed been great, and the Royal College of Physicians wisely broke with tradition when its Fellows elected him President in 1962-the first, we believe, who has not been a practising physician.

Like Dodds, Sir Solly Zuckerman, F.R.S., who is appointed K.C.B., is a brilliant all-rounder. Professor of anatomy at Birmingham from 1946, Zuckerman has combined funda-

1 Bodenham, D. C., Brit. med. F., 1961, 2, 1574.

2 Outwin, G. R., Brit. med. F. Suppl., 1962, 2, 77.

s Congenital Malformations. Standing Medical Advisory Committee for the Central Health Services Council. Ministry of Health, London. 1963.

- Smith, R., Brit. med. 7. Suppl., 1962, 2, 78.

s Leck, I., Brit. med. F., 1963, 1.807.

- McDonald, A., Brit. F. prev. soc. Med., 1961, 15, 154.

7 Watson, G. I., Slater, B. C. S., and McDonald, J. C., Brit. med. F., $1962,1,793$. mental research into the anatomy, physiology, and behaviour of primates with operational research into problems of both war and peace. As chief scientific adviser to the Ministry of Defence and a member now and formerly of many Government committees he has played a large part behind the scenes in keeping successive administrations properly informed of the latest technical developments.

Among the new knights we note with pleasure the dean of Guy's Hospital Medical School, Dr. E. R. Boland. Since 1945, when he entered this appointment, his name has been inseparable from that of the hospital itself, to which he has devoted his great gifts of fair administration, understanding of young people, and personal courage. Dr. J. H. Gaddum, F.R.S., is one of our most distinguished pharmacologists, whose researches have included important studies of the substances liberated on stimulation of autonomic nerves. To the assay of hormonal and other substances, which has also engaged his interest, he brought novel statistical techniques that have proved of great help. His present appointment as director of the Institute of Animal Physiology at Cambridge was preceded by professorships of pharmacology in Cairo, London, and Edinburgh. Mr. H. J. Seddon's great contributions to the development and practice of orthopaedic surgery are well known. As director of studies at the Institute of Orthopaedics his stimulating influence has been felt far beyond the confines of the Royal National Orthopaedic Hospital, while his reparative work in cases of poliomyelitis contributed notably to the international reputation that is his. Dr. Barnett Stross, who receives a knighthood for political and public services, has been a Labour Member of Parliament since 1945, formerly for Hanley and now for Stoke-on-Trent. Much of his life has been devoted to improving conditions in the Potteries, while in Parliament he has provided a constant stimulus to the improvement of the Health Service, advocating greater capital expenditure on hospitals and on research. We are also delighted to see the names of two distinguished Australians among the knights-namely, Professor J. B. Cleland, emeritus professor of pathology at Adelaide, and Dr. V. M. Coppleson, a well known surgeon in New South Wales.

It was a happy thought to award the O.B.E. to both husband and wife-Dr. John and Dr. Valerie Graves-in recognition of their valuable work for the College of General Practitioners. The full list of honours appears on p. 113.

\section{Circulation of Cerebrospinal Fluid}

After being formed in the choroid plexuses of the lateral ventricles the cerebrospinal fluid (C.S.F.) passes through the ventricular system, circulates in the subarachnoid spaces, and is reabsorbed through the arachnoid villi into the great venous sinuses. Has this textbook "knowledge" a firm foundation? The clinician would say it has, but some workers have raised doubts, ${ }^{12}$ and it has been suggested that formation and absorption take place widely throughout the C.S.F. pathways, including the perivascular spaces and the sheaths of the nerve roots. The evidence has been reviewed by $J$. W. Millen and D. H. M. Woollam ${ }^{3}$ and now in detail by D. W. C. Northfield." Research in Boston ${ }^{5-7}$ and by D. R. Bowsher ${ }^{8}$ in Great Britain suggests that the choroid plexus is indeed an important site for the passage of certain ions from plasma to C.S.F., but is this by simple filtration or by active secretion, 
and is fluid actually formed there ? Careful comparison with an ultrafiltrate of plasma $^{9}$ shows that the C.S.F. differs from it in containing, for instance, a higher concentration of sodium and chloride. Such variation must surely result from active secretion. The sodium then will play a part in maintaining slight hypertonicity of the C.S.F., and this will attract fluid. The concentration of sodium being greatest at the choroid plexus, it is there that conditions most favour the movement of fluid from plasma to C.S.F.

These observations fit well with the established facts of clinical experience. If the aqueduct of Sylvius is blocked the lateral and third ventricles dilate and high pressure develops. If one foramen of Monro is blocked that ventricle alone will dilate. A temporal horn obstructed by adhesions will dilate into a large cyst unless the choroid plexus is destroyed-a procedure which has long been advocated by J. E. Scarff ${ }^{10}$ for the treatment of hydrocephalus.

The classical theory of absorption, however, has not the same strong support. Identifiable substances introduced into the C.S.F. have been shown apparently passing through the arachnoid villi, but they may themselves have caused alterations in permeability, and some have not been found on the venous side. Water molecules introduced into the C.S.F. pass rapidly into the plasma, but this is not true of other ions. Moreover, there are no capillaries in the pia, ${ }^{11}$ and it is hard to accept that absorption takes place directly into larger vessels. Northfield stresses the importance of pressure relationships. If the pressure of the C.S.F. is suddenly raised by injections of saline ${ }^{12}$ it returns so quickly to normal that the increase of pressure must have started a process of absorption. But if the pressure in the cortical veins were not higher than in the C.S.F. they would collapse, and indeed it appears that this happens, for when the C.S.F. pressure is quickly raised the blood flow in the sagittal sinus drops abruptly. However, a slow rise in pressure results in increased blood flow in the sinus. Pressure of blood in the sinus is normally below that of the C.S.F., but the structure of the sinus prevents collapse. A gradation of pressure can thus exist which makes absorption a practical possibility at this site, while it might not be possible directly into cortical veins.

The clinician knows that if C.S.F. cannot get to the surface of the cerebral hemispheres as a result, for instance, of obliteration of the tentorial hiatus, then hydrocephalus ensues, and this may also follow sagittal-sinus thrombosis. Apparently excess fluid cannot be adequately absorbed into meningeal veins or perineural lymphatics. High pressure also develops sometimes long after a subarachnoid haemorrhage, in the Guillain-Barré syndrome, or even in the presence of a neurofibroma which is not in any way obstructing the ventricular

1 Schaltenbrand, G., and Bailey, P., F. Psychol. Neurol. (Lpz), 1928, 35, 199.

- Sweet, W. H., Brownell, G. L., Scholl, J. A., Bowsher, D. R., Benda, P., and Stickley, E. E., Res. Publ. Ass. nerv. ment. Dis., 1954, 34, 101.

s Millen, J. W., and Woollam, D. H. M., The Anatomy of the Cerebrospinal Fluid, 1962, London, Oxford University Press.

Northfield, D. W. C., N.Z. med. F., 1963, 62, 167.

s Sweet, W. H., and Locksley, H. B., Proc. Soc. exp. Biol. (N.Y.), 1953, 84, 397.

- Selverstone, B., The Cerebrospinal Fluid, 1958, Ciba Foundation Symposium, London, Churchill.

Bakay, L., The Blood-Brain Barrier, 1956, Thomas, Springfield.

"Bowsher, D. R., The Cerebrostinal Fluid, 1958, Ciba Foundation Symposium, London, Churchill.

- Davson, H., Physiology of the Ocular and Cerebrospinal Fluids, 1956, London, Churchill.

10 Scarf, J. E., ₹. Neurol. Neurosurg. Psychiat., 1963, 26, 1.

1 Wonllam, D. H. M., and Millen, J. W., The Cerebrospinal Fluid, 1958, Ciba Foundation Symposium, London, Churchill.

12 Ryder, H. W., et al., F. Lab. clin. Med., 1953, 41, 428.

is Dandy, W. E., Ann. Surg., 1919, 70, 129. system. It is tempting to attribute this to obstruction of the villi by blood clot or highly proteinous fluid, though it may be argued that such obstruction could be in the absorption areas of the nerve roots.

It is evident that Dandy's ${ }^{13}$ ideas on the formation of C.S.F. have strong clinical and experimental support, but the evidence is less strong for absorption by the villi. It may take place there, and the theory serves the clinician well ; but further evidence is needed before we can be certain that the villi are the only site at which the fluid is reabsorbed.

\section{Oedema in Rheumatoid Arthritis}

Local accumulations of fluid in the tissues outside the vascular system provide evidence of imbalance between the factors that control the interchange of fluid between the intravascular and extravaścular compartments of the body. Fluid normally leaves the capillaries because of the difference in hydrostatic pressure across the capillary endothelium, but the rate of its passage is restricted by the difference in osmotic pressure exerted by the macromolecules on either side of the endothelium. Within the vessels the macromolecules mainly responsible are the albumin and to a much lesser extent the alpha ${ }_{1}$-globulins; outside them the macromolecules normally present-for example, hyaluronic acid-are too large to exert any significant osmotic pressure. The fluid that leaves the capillaries normally follows one of two routes: it may be reabsorbed at the venous ends of the capillaries where the filtration pressure can be presumed to have fallen below the osmotic pressure of the plasma proteins, or it may be removed via the lymphatics aided by the pumping effect of muscular activity.

Thus local accumulations of extravascular fluid can arise in three ways - by failure of reabsorption into the distal parts of the capillaries, by impairment of lymphatic drainage, and by increased permeability of the capillary walls as in inflammation. A fairly accurate indication of which of these is operative in any individual patient can be obtained by estimating the concentration of protein in the oedema fluid. In inflammatory oedema plasma proteins pass through the capillary walls and are present in the oedema fluid in amounts approaching those of the plasma-that is, 4 to $6 \mathrm{~g} / / 100 \mathrm{ml}$. In cases of lymphoedema much lower concentrations are found, and even in chronic cases the concentration rarely reaches $4 \mathrm{~g}$. $/ 100 \mathrm{ml}$. When oedema results from factors disturbing the reabsorption of the normally transuded fluid its protein concentration is exceedingly low and rarely exceeds $1 \mathrm{~g} . / 100 \mathrm{ml}$.

The nature of the oedema commonly seen in the feet and ankles of patients with chronic rheumatoid arthritis is a matter of interest for the light it might throw on the rheumatoid process itself. Miss Dorothy C. Park and Dr. $K$. Swinburne have therefore studied this oedema fluid, and their results, published at page 86 of the B.M.F. this week, show conclusively that it is not the result of local inflammation. The mean concentration of protein in 16 patients was only $0.59 \mathrm{~g} . / 100 \mathrm{ml}$., with a range of $0.16-1.10 \mathrm{~g} . / 100 \mathrm{ml}$.

In the absence of hypoproteinaemia, congestive cardiac failure, or lymph stasis it is difficult to account for the

' Ragan, C., and Meyer, K., f. clin. Invest., 1949, 28, 56. - Bywaters, E. G. L., Holborow, E. J., and Keech, M. K., Brit. med. F.,
1951, 2, 1178 . 